\section{Saša Živković}

Graduate student Military technical institute

Momčilo Milinović

Full Professor

University of Belgrade

Faculty of Mechanical Engineering

Norbert Adamec

Assistant Professor Academy of the Armed Forces "gene. M. R. Stefanik"

Department of Mechanical Engineering

\section{Experimental and Numerical Research of a Supersonic Planar Thrust Vectoring Nozzle via Mechanical Tabs}

Wind tunnel cold flow tests were conducted, using the convergentdivergent two-dimensional nozzle, with a tab as the obstacle at the nozzle exit area. This geometry is applied in thrust vector control systems for missiles. During the variation of some of the most influential geometry parameters in the flow domain, the nozzle surface pressure distribution is measured, and the Schlieren photos are recorded. Using those experimental results, CFD modeling is conducted, and four turbulence models are compared. After comparison, the advantage is given to transitional $k-\omega$ turbulent models, regarding results concurrence and computational cost. These results can be used as a guideline for further three-dimensional CFD researches of real thrust vector control geometries, and also for a better understanding of flow processes in those applications.

Keywords: TVC, two-dimensional, nozzle, wind tunnel, separated flow, CFD, turbulence model

\section{INTRODUCTION}

The aim of this research is to gain a better understanding of the fluid flow process under high speed gas flow conditions, so as to control flow parameters to cover the design process of the thrust vector control (TVC) system [1]. Mechanical types of TVC systems are still commonly used. They are applied in the tactical as well as large caliber rockets and missiles. Over the past decades, researches of the mechanical TVC systems have become of great interest [2]. In their earlier works, authors have developed many semi-empirical models that were applied in twodimensional and three-dimensional geometry flow [3]. In that period, CFD methods were not fully developed as a calculation tool. Today, similar researches are actual involving the nozzle flow in TVC systems which use the secondary fluid injection [4, 5]. Nozzle flow under these two types of disturbances made by the TVC systems (flow injection and mechanical obstacles) is similar, and calculation methodology can be used as common methodology.

Furthermore, the paper presents experimental and simulation research of the supersonic flow in twodimensional convergent-divergent (con-di) nozzle with "axial" obstacle at the exit plane (nozzle tab) [6]. The experiments were conducted in the wind tunnel T-36 at the Military Technical Institute of Serbia [3]. This examination is the first phase in research of the gasdynamic processes in propulsion systems with TVC devices [1]. As reported in earlier works [3], twodimensional separated flow is quite different from that in real missile three-dimensional geometry. This is

Received: March 2014, Accepted: May 2014

Correspondence to: Saša Živković

Military Technical Institute,

Ratka Resanovića 1, 11030 Belgrade, Serbia

E-mail: sasavite@yahoo.com

doi:10.5937/fmet1403205Z

(C) Faculty of Mechanical Engineering, Belgrade. All rights reserved related to the curved walls in three-dimensional nozzles, which have strong lateral effects on the separation point position and recirculation zone parameters. For these reasons, the experiments could not be directly applied to real missile geometry, but some important discoveries and relations could be very useful in further researches. Based on the experiments, CFD numerical simulations are conducted with four turbulence models. Using the results of those simulations, CFD calculation process is proven and the most appropriate turbulence model is chosen for further phases of TVC tree-dimensional geometry examination.

The CFD methods in flow calculations in those conditions generally give a good agreement with experiments. The majority of authors agreed that turbulence models have significant impact on the accuracy of calculation [7].

\section{STATE OF THE ART}

During the supersonic fluid flow over the obstacles a recirculation zone is accruing, followed by boundary layer separation and oblique shock wave generation in supersonic stream [8]. The physical model of this process is presented in figure 1. Recirculation zone is shaped in the form of so-called "liquid wedge", which causes boundary layer separation, supersonic flow deflection and consequently shock waves generation. Disturbed flow field produces asymmetric pressure distribution on the nozzles' walls, which generates a component of the pressure force, perpendicular to the nozzle axis (side force). This component is interdentally produced and serves as the flight control force on the propelled flight vehicle.

Characteristic parameters of this gas flow process, which determination is the main goal of this research, are next:

- pressure distribution on inner nozzle surfaces;

- recirculation zone shape and position; 
- shock waves shape and position;

- influence of the flow trough the gap between the tab and the nozzle exit surface (tab gap).

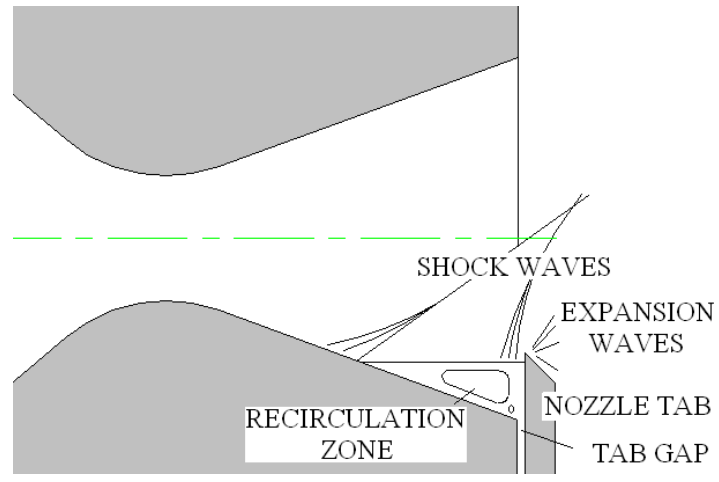

Figure 1. Physical model of the supersonic flow in nozzle with the tab.

Earlier researches [3, 1], conform design performances, as significant impact values in the process of determining the side force, in the order as follows:

- height of the nozzle tab relative to nozzle exit height (shadowed ratio);

- angle between the nozzle tab and nozzle axis;

- tab gap;

- expansion ratio of the nozzle;

- expansion angle of the nozzle;

- shape of the tab.

Experimental research and conducted numerical modeling with CFD software package FLUENT [9] provide the variation of conditions and mentioned parameters of supersonic flow in the nozzle with axial obstacle. Selected experiments are reproduced by the CFD simulation in order to verify the used numerical model. Many authors have noted a noticeable difference between the results of the CFD simulations in similar applications [7, 6]. These differences are the most noticeable in the vicinity of the recirculation zone and the separation point. Some of the varied turbulence models are later on, and they are especially designed to solve the problems with the transition of the laminar boundary layer into the turbulent one. This process is conspicuous in the separation point area, and in this zone those models can come to the fore.

The most important contribution of the CFD simulation is choice of the turbulence model trough experimental verification, and boundary layer functions of the nozzle wall.

Results of the experiments and the simulations are compared: qualitatively, regarding the shape and position of the recirculation zone and shock waves; and quantitatively, comparing pressure distribution on the nozzle lower surface.

\section{EXPERIMENTAL MODEL AND TEST CONDITIONS}

Geometry of the experimental model is determined on the basis of the real missile TVC system geometry and working conditions. Also, the geometry is adjusted to wind tunnel test chamber dimensions.

The nozzle contour is formed using the upper and lower parts which are mounted into the test chamber of the wind tunnel (figure 2). The parts are formed on the metal frame which holds nozzle walls elements. The elements are: convergent, throat and divergent plate. All elements are made from steel with polished surfaces. Joints of the plates are coated with epoxy glue and are also polished.

The nozzle expansion ratio can be adjusted by setting the distance between the parts. Minimum height of the throat is $50 \mathrm{~mm}$, which corresponds to 2.9 value of the expansion ratio. Maximum height is $78 \mathrm{~mm}$, and expansion ratio is 2.2 .

Test chamber width is $249 \mathrm{~mm}$ and nozzle length is $460 \mathrm{~mm}$. The ratio of other important nozzle dimensions to the chamber width is given in table 1 . Smaller values of these ratios mean smaller lateral walls' influence on the flow, i.e. better two-dimensionality of the flow. The most important ratio is the exit nozzle height to the width, because recirculation zone is placed in this area. This ratio is 0.69 , which is a relatively high value and side walls' influence is certainly present.

Table 1. Nozzles geometry ratios.

\begin{tabular}{|c|c|c|c|}
\hline $\begin{array}{c}\text { Throat height } \\
{[\mathrm{mm}]}\end{array}$ & $\begin{array}{c}\text { Thr. height/ } \\
\text { width }\end{array}$ & $\begin{array}{c}\text { Exit height/ } \\
\text { width }\end{array}$ & $\begin{array}{c}\text { Lenght/ } \\
\text { width }\end{array}$ \\
\hline 50 & 0.2 & 0.58 & 1.85 \\
\hline 78 & 0.31 & 0.69 & 1.85 \\
\hline
\end{tabular}

The tab is hitched on the lower part of the nozzle, and can be positioned at different heights, realizing different shadowed ratios of the nozzle exit plane. This allows for the examination of the shadowed ratio influence on the fluid disturbed flow. The tab can be also positioned at different distances from the nozzle exit plane, in order to examine the tab gap influence.

Lateral sides of the nozzle parts have fillisters for rubber gaskets which overlap on transparent walls of the tunnel test chamber. This configuration enables fluid flow visualization using the Schlieren technique.

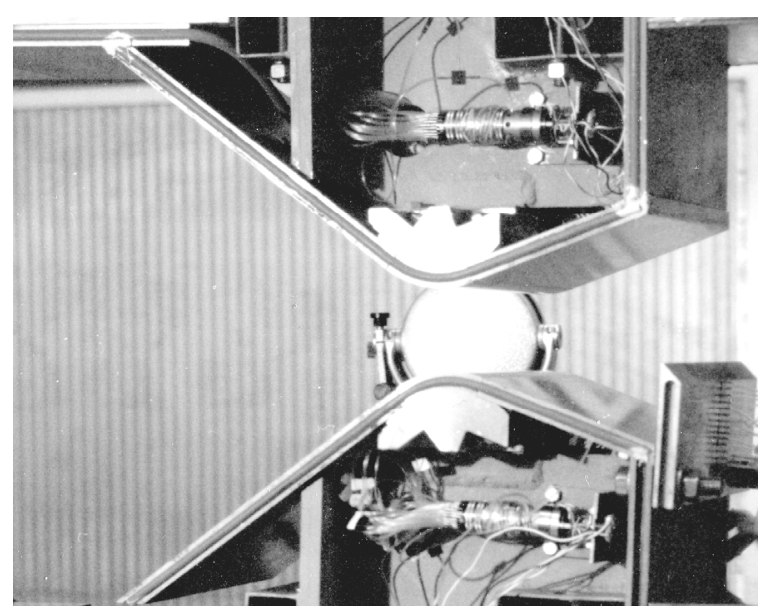

Figure 2. Experimental model in wind tunnel test chamber.

The pressure measurement is conducted with three instruments type "Scanivalve" - model S, each with 48 measurements channels. A measurement of the flow parameters is provided with the wind tunnel supporting equipment.

For measuring the pressure on the nozzle walls, elements have drilled holes, $1 \mathrm{~mm}$ in diameter each, and plastic tubes with inner diameter $0.5 \mathrm{~mm}$ are inserted into them. Respecting the manufacturer's 
recommendation for pressure measurements, using special plastic hoses with inner diameter $1 \mathrm{~mm}$, tubes are connected with measurement instruments. The diameter of the tubes is optimal, and provides negligible disturbance of the flow field, and large enough orifices to prevent chocking by silica gel particles present in dry-air stream. Measurement points are positioned on the central line of the upper and lower divergent part of nozzle walls. Holes' distances are $5 \mathrm{~mm}$.

Besides mentioned measurements, the Schlieren imaging with color filters is conducted to enable flow visualization. The measurement process is computer controlled, and the program defines timing and measuring cycle of the wind tunnel tests. Three seconds, after the test start and air flow stabilization, pressure measurements begin, using the recommended procedure. In the first measurement point, the instrument takes 50 pressure samples for 0.15 seconds, the sampling rate of the system is $333 \mathrm{~s}^{-1}$, and the computer memorizes mean value. This procedure is repeated for all measurement points, and duration of the entire test is approx. 35 seconds.

Wind tunnel air flow is dived using vacuum tank at the rear end. To achieve the desired Mach numbers 2.3 and 2.6, a high vacuum level in the tank is required during the cycle operation time. The required total to static pressure ratio is over 20 , so the maximum allowed pressure level in the tank is 50 mbar. The capacity of wind tunnel equipment, regarding these requirements, enables the next tunnel operation parameters: vacuum tank pressure at cycle beginning 5 mbar, and 50 mbar at the end of the cycle, after filling with air. For both configurations, the nozzle ideal static expansion pressure is over 50 mbar. During the experiment, until pressure in the vacuum tank reaches the allowed level, the mass flow rate and other flow parameters in nozzle exit vicinity are constant. Wind tunnel is also equipped with the system for air drying.

During the experiments, additional wind tunnel operating parameters are controlled:

- atmospheric pressure;

- air temperature in setting chamber, before collector section;

- referent Mach number in setting chamber;

- total and static pressure in collector section;

- total pressure in test section.

The main flow characteristics measured in wind tunnel sections, averaged for presented experiments, are shown in Table 2. Geometry and flow parameters of the nozzle for both expansion ratio configurations are given in the same table.

Table 2. Wind tunnel flow conditions and nozzles geometry

\begin{tabular}{|c|c|c|c|c|}
\hline $\begin{array}{c}\text { Atmosphere } \\
\text { pressure } \\
{[\mathrm{mbar}]}\end{array}$ & $\begin{array}{c}\text { Stilling ch. } \\
\text { pressure } \\
{[\mathrm{mbar}]}\end{array}$ & $\begin{array}{c}\text { Test sec. } \\
\text { pressure } \\
{[\mathrm{mbar}]}\end{array}$ & $\begin{array}{c}\text { Test sec. } \\
\text { temperature } \\
{[\mathrm{K}]}\end{array}$ & $\begin{array}{c}\text { Vac. tank } \\
\text { pressure } \\
{[\mathrm{mbar}]}\end{array}$ \\
\hline 1018.3 & 1015.8 & 1010.5 & 286.5 & $5-50$ \\
\hline
\end{tabular}

\begin{tabular}{|c|c|c|c|c|}
\hline $\begin{array}{c}\text { Throat } \\
\text { height } \\
{[\mathrm{mm}]}\end{array}$ & $\begin{array}{c}\text { Exit pl. } \\
\text { height } \\
{[\mathrm{mm}]}\end{array}$ & $\begin{array}{c}\text { Expansion } \\
\text { ratio }\end{array}$ & $\begin{array}{c}\text { Ex. Mach } \\
\text { number }\end{array}$ & $\begin{array}{c}\text { Reynolds } \\
\text { number } \\
{[\mathrm{Re} / \mathrm{m}]}\end{array}$ \\
\hline 50 & 145 & 2.9 & 2.6 & 9680000 \\
\hline 78 & 174 & 2.2 & 2.3 & 11250000 \\
\hline
\end{tabular}

The examination program was very extensive. The measurements of pressure profiles on the lower divergent plate are conducted by varying the next model configurations:

- shadowed ratio;

- tab gap;

- nozzle expansion ratio;

- angle between the tab and nozzle axis;

- shape of the tab.

Besides main measurements, several other examinations are conducted:

- pressure distribution on upper divergent plate;

- pressure measurement in points closer to test chamber side walls, for two-dimensionality testing;

- pressure distribution on both sides of the nozzle tab;

- Schlieren imaging.

Research was divided into three phases:

Phase 1: examination of the most influential parameters of the experimental geometry configuration on fluid flow as it shadowed the ratios and the tab gaps.

Phase 2: examination of the nozzle tab angles' influence with different tab gaps.

Phase 3: examination of the tab shapes.

Selected ranges of influenced parameters for tests and analyses are:

- shadowed ratio $10 \%, 20 \%$ and $30 \%$;

- tab gap 0, 2. 1, 6.3 and $13.3 \mathrm{~mm}$;

- expansion ratios are 2.2 and 2.9.

\section{EXPERIMENTAL RESULTS}

Figure 3 shows pressure profiles on the lower divergent plate, along the nozzle axis $(x-$ axis), for three values of the shadowed ratio 10,20 and $30 \%$. Nozzle configuration is with the 2.2 expansion ratio. For the shadowed ratio $10 \%$, pressure decreases from the nozzle throat toward the nozzle tab. Near the $x$ - axis value $0.7 \mathrm{~m}$, pressure suddenly increases in the zone of the separation point, and then the value remains constant in the recirculation zone, so called plateau pressure value [8]. Figure 4 shows the Schlieren photography of this test. The photography shows only the divergent part of the nozzle, where the recirculation zone and shock waves is located. The recirculation zone and oblique shock wave can be easily recognized.

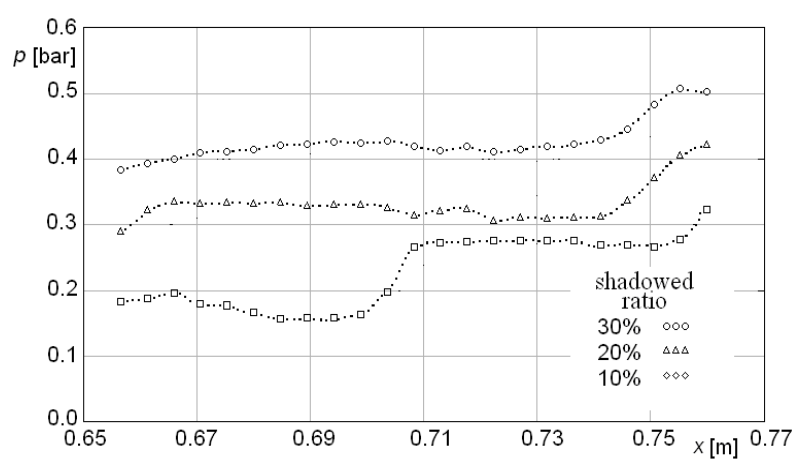

Figure 3. Pressure distribution along the nozzle axis, for shadowed ratio variation. Nozzle expansion ratio 2.2.

With a higher level of the shadowed ratio, the separation point is moving toward the nozzle throat. For 
the $20 \%$ shadowed ratio, the plateau pressure is higher than for $10 \%$, and the separation point is moved before the first measurement point. Schlieren photography in figure 5 confirms those conclusions. In this photography, strong interaction between the boundary layer and the oblique shock wave can be noticed, and the formation of so called $\lambda$-wave. For the $30 \%$ shadowed ratio the plateau pressure is even higher, and the separation point is closer to the nozzle throat.

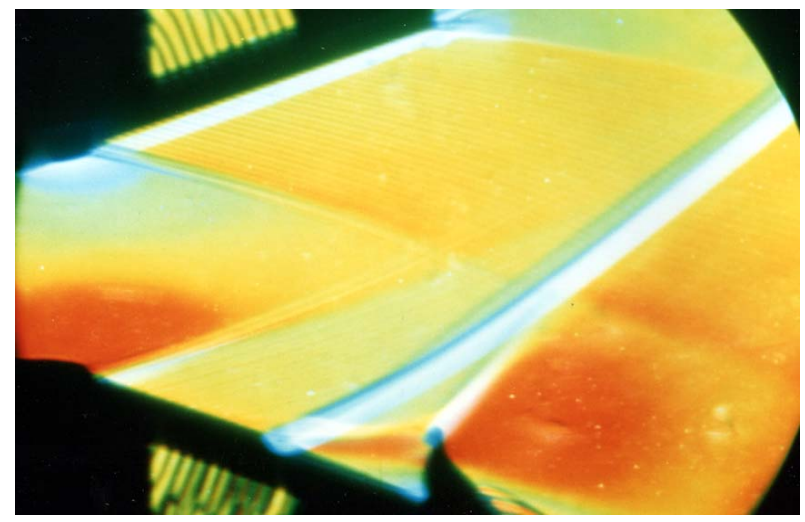

Figure 4. Schlieren photography of experiment: expansion ratio 2.2 , shadowed ratio $10 \%$ and tab gap $0 \mathrm{~mm}$.

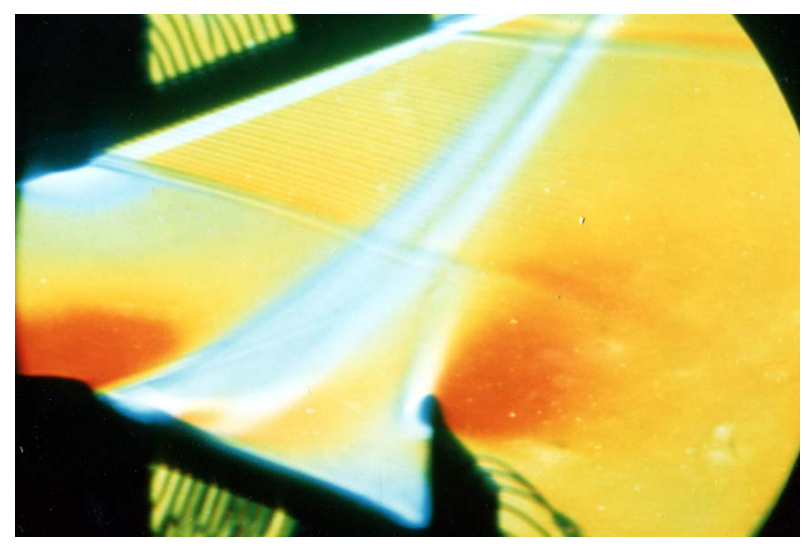

Figure 5. Schlieren photography of experiment: expansion ratio 2.2 , shadowed ratio $20 \%$ and tab gap $0 \mathrm{~mm}$.

The tab gap influence is presented in figure 6 , like pressure distribution along the $x$ - axis, for the nozzle with the 2.2 expansion ratio. The tab gap is expressed as a relative value to the exit nozzle height - relative gap. With a smaller gap increase, the separation point is moving closer to the nozzle tab, and the plateau pressure slightly decreases. With more significant relative tab gap increase $(9.7 \%)$, the separation point position and the plateau pressure change is much more noticeable.

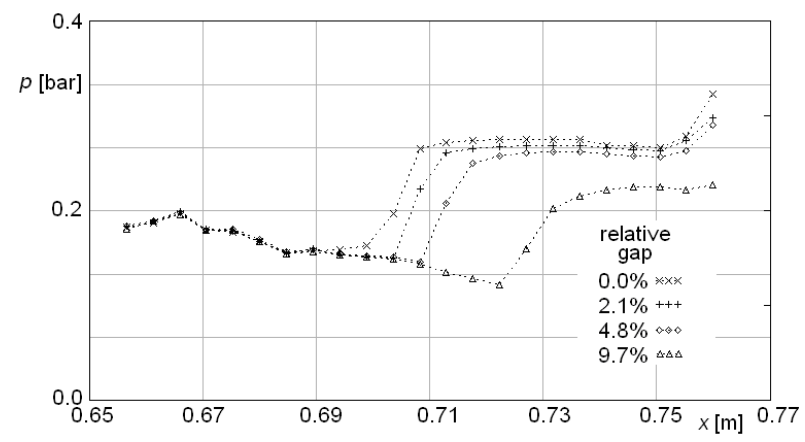

Figure 6. Pressure distribution along the nozzle axis, for tab gap variation. Nozzle expansion ratio 2.2.
Figures 4, 7 and 8 display Schlieren photos of the experiments. In the photos, the separation zone size decrease can be noticed, as well as change in the recirculation zone position, which corresponds to the pressure profiles in figure 6.

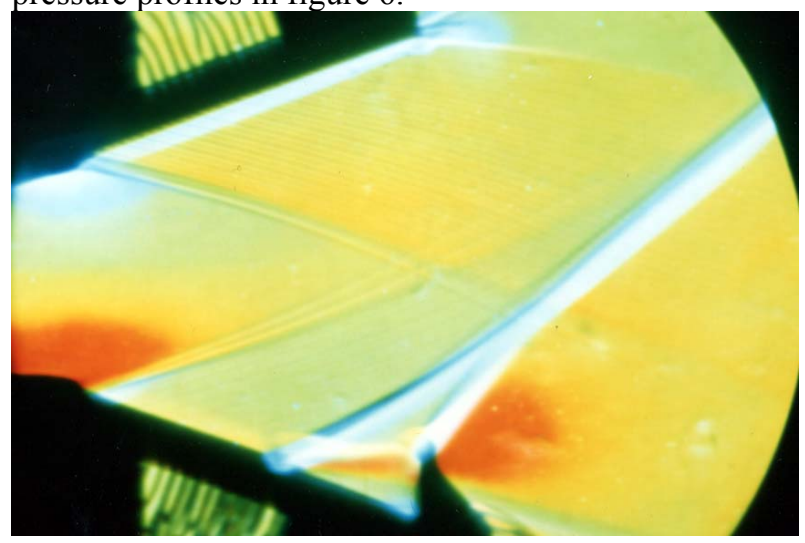

Figure 7. Schlieren photography of experiment: expansion ratio 2.2 , shadowed ratio $10 \%$ and tab gap $2.1 \%$.

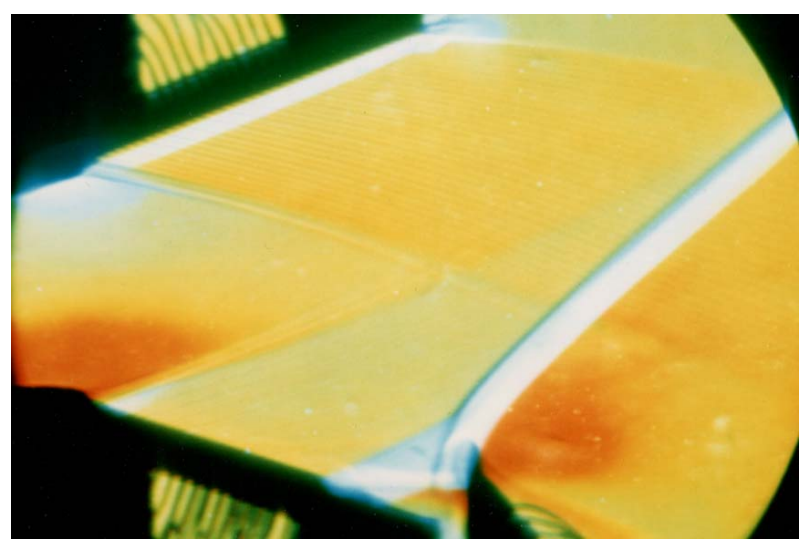

Figure 8. Schlieren photography of experiment: expansion ratio 2.2 , shadowed ratio $10 \%$ and tab gap $9.7 \%$.

The influence of the expansion ratio is shown in figure 9, using pressure distribution along the $x$ - axis for two nozzle configurations: expansion ratios 2.2 and 2.9 .

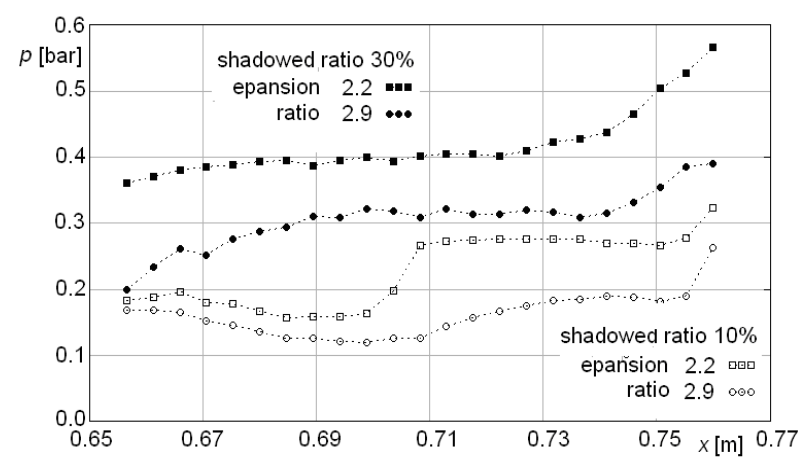

Figure 9. Pressure distribution along the nozzle axis, for expansion ratio variation, for shadowed ratios $10 \%$ and 30 $\%$.

Curves are shown for two values of the shadowed ratio, $10 \%$ and $30 \%$. At expansion ratio 2.9 for both values of the shadowed ratio, the plateau pressure is lower and the separation point is closer to the nozzle tab (Schlieren photo for experiment with $30 \%$ shadowed ratio is given in figure 11). When two lower curves are compared for shadowed ratio $10 \%$, pressure 
distribution for expansion ratio 2.9 (the lowest curve) has much looser increase of the pressure level in the vicinity of the separation point than for expansion ratio 2.2. The explanation of this occurrence could be more intensive interaction between the shock wave and the boundary layer, for 2.9 expansion ratio than for 2.2 . In Schlieren photos of the two experiments (figures 4 and 10), this effect can be noticed.

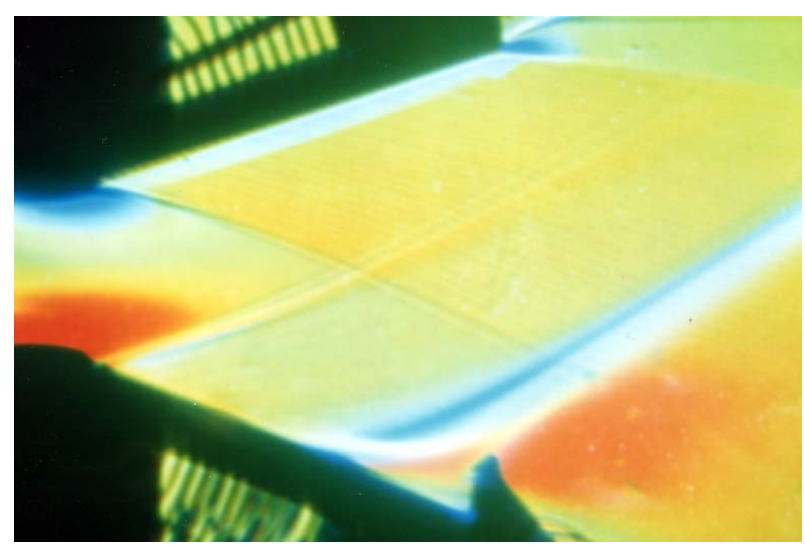

Figure 10. Schlieren photography of experiment: expansion ratio 2.9 , shadowed ratio $10 \%$ and tab gap $0 \mathrm{~mm}$.

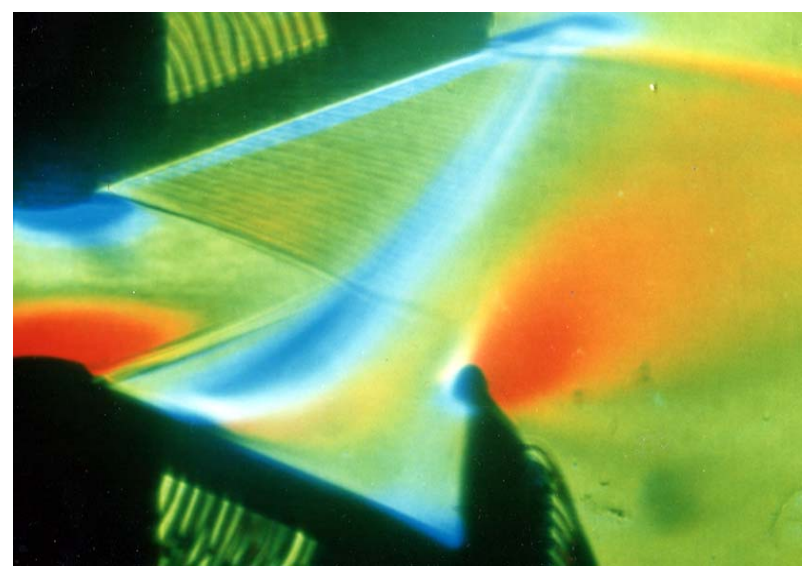

Figure 11. Schlieren photography of experiment: expansion ratio 2.9 , shadowed ratio $30 \%$ and tab gap $0 \mathrm{~mm}$.

\section{CFD CALCULATION}

The developed wind tunnel model with two-dimensional flow characteristics is scaled with the factor ten compared to the real designed nozzle throat $(7.8 \mathrm{~mm})$ used for the TVC equipment.

For CFD modeling, two-dimensional geometry is also used. The flow domain shape with calculation mesh is shown in figure 12. Hybrid mesh is applied. The convergent part of the model and zones of the boundary layers are filled with a structural mesh. The unstructured mesh is applied in the divergent part of the nozzle, where intense vortices and flow deflection are expected. In boundary layer zones, mesh is fine enough to achieve unitless height value of the wall neighbor cell $y^{+} \approx 1$, which is recommended in [9].

Boundary layer thickness is less than $0.5 \mathrm{~mm}$, and mesh quality in this zone is achieved using the adaptation technique. This thickness is covered with four layers of cells, and during calculation each cell adjacent to the wall is divided in four cells, regarding the procedure described in [9]. This procedure is repeated several times until desired value of $y^{+}$is achieved.

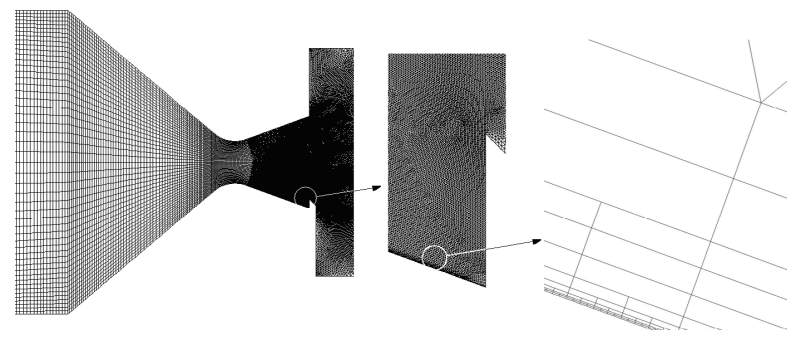

Figure 12. Two-dimensional domain with mesh for CFD calculation, and boundary layer mesh details.

The experiment with expansion ratio 2.2, shadowed ratio $10 \%$ and without tab gap is chosen for CFD simulation to investigate the applicability of available turbulent models in the Fluent. Figure 13 shows pressure distribution on the lower divergent plate for mentioned experiment and for simulations with different turbulent models.

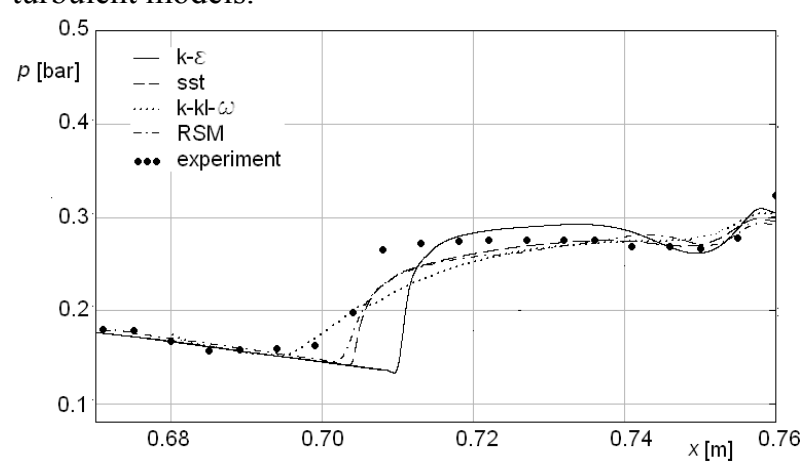

Figure 13. Comparison of pressure distribution along the nozzle axis for CFD simulation and experiment. Geometry characteristics are: expansion ratio 2.2, shadowed ratio 10 $\%$ and zero tab gap.

Comparing experimental and CFD pressure curves in separation zone can be concluded that resolution of the measurement points is acceptable in zones with small pressure gradients. In vicinity of separation point and also in zone near nozzle tab, better resolution is desirable. In those two zones largest experimental and CFD results disagreement is noticed. Unfortunately experiment conditions dictates uniform distribution of the measurement points.

During numerical research, four mathematical turbulent models are used in CFD simulation. Each one had enhanced wall treatment for the boundary layer derivation (terminology from [9]).

First turbulent model was RNG k- $\varepsilon$ model as the most appropriate, regarding all other $\mathrm{k}-\varepsilon$ variants because it is designed for swirl flow with boundary layer separation [9]. Nevertheless, this model has the largest deviation of results, in comparison to other models, which can be seen in figure 13 .

Figure 14 shows graphical results of this simulation: contours of density field in divergent part of the nozzle, and also the velocity vectors in the recirculation zone. In comparison with the Schlieren photography of equivalent experiment (figure 4), similarity is noticeable in the shape and position of the oblique shock wave and 
recirculation zone. In figure 14 - right, magnification of the recirculation zone is shown. Two main vortices can be identified. The first larger vortex is placed after the separation point and has a relatively large velocity level, up to $100 \mathrm{~m} / \mathrm{s}$. This vortex extends almost over the entire recirculation zone and its pressure defines the plateau pressure level. The smaller vortex is lined on the nozzle wall and the tab. Much stronger viscosity effect conditions lower the velocity level below $20 \mathrm{~m} / \mathrm{s}$, and produce a higher pressure level. This higher pressure zone, lined on the tab, has significant influence on thrust losses.

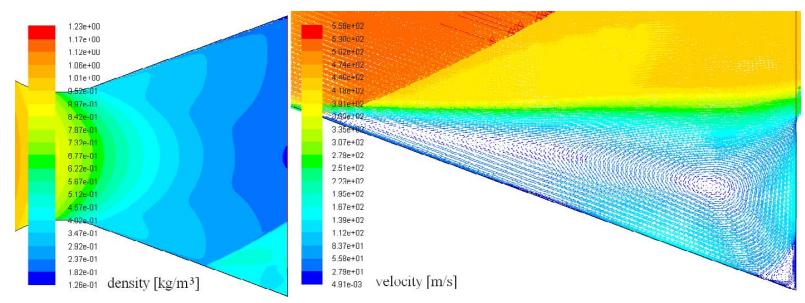

Figure 14. Contours of density and velocity vectors of CFD simulation with $k-\varepsilon$ turbulence model.

The second CFD test was performed using the transition SST turbulent model, based on the k- $\omega$ mathematical approach, and results are represented on the curve in figure 13. This is four-equation turbulence model with four independent turbulence characteristics: turbulent kinetic energy, specific dissipation rate, intermittency, and Reynolds number based on the transition momentum thickness of boundary layer [9]. Those parameters enable more accurate calculation of the laminar - turbulent transient process in the boundary layer.

Analyzing graphical results of this simulation (figure 15), the shape and position of the recirculation zone and oblique shock wave, it can be noticed that they follow the shape observed in the Schlieren photography in the same experiment (figure 4). The pressure distribution curve also has a good agreement with experimental results (figure 13).

Analyzing graphical results of this simulation (figure 15), the shape and position of the recirculation zone and oblique shock wave, it can be noticed that they follow the shape observed in the Schlieren photography in the same experiment (figure 4). The pressure distribution curve also has a good agreement with experimental results (figure 13).

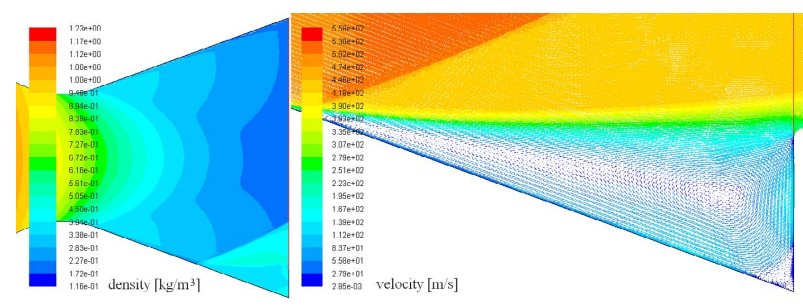

Figure 15. Contours of density and velocity vectors of CFD simulation with SST turbulence model.

The thread tested turbulent model was also a transition variation of the $\mathrm{k}-\omega$ turbulence model - threeequation transition k-kl- $\omega$ model. The shape and position of the recirculation zone and shock wave are similar to previous model (figure 16). Some difference still exists. The separation point is closer to the nozzle throat, and oblique shock wave is more bended in the vicinity of the wall. The pressure curve for this model has better agreement with the experiment in the vicinity of the separation point, but poorer agreement of the plateau pressure level (figure 13).

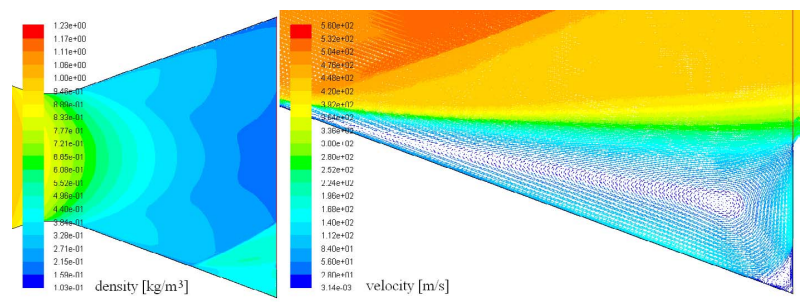

Figure 16. Contours of density and velocity vectors of CFD simulation with k-kl- $\omega$ turbulence model.

The fourth tested turbulence model was fiveequation Reynolds stress model (RSM). This is the most expensive model as for the computational cost. Unlike this model, all three previous turbulence models are based on the Boussinesq hypothesis, with isotropic approximation of turbulent viscosity. RSM model calculates Reynolds turbulent stresses and it is possible that it is more adequate for this problem, because of large velocity gradients in the recirculation zone. Nevertheless, RMS model gives very similar results with SST model, regarding pressure distribution (figure 13), and shape and position of the recirculation zone and oblique shock wave (figure 17).

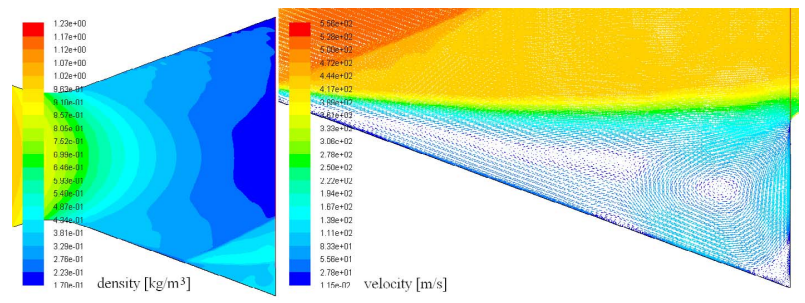

Figure 17. Contours of density and velocity vectors of CFD simulation with RSM turbulence model.

It is obvious that, in this case, the transient $\mathrm{k}-\omega$ models give similar results like RMS model. Regarding their lower computational cost, they are more appropriate for calculation in three-dimensional models [9].

\section{CONCLUSION}

This paper describes experimental determination of wind tunnel two-dimensional air flow parameters. The main activity was measuring of pressure distribution along the wall of the nozzle divergent part in the vicinity of the nozzle tab. During described experiments the Schlieren photos are also recorded. Those experimental results contributed to basic knowledge of flow processes and they were crucial in mathematical modeling, in real rocket TVC systems. Attention was drawn to the processes of recirculation zone formation and boundary layer separation. The most important contribution of the CFD simulation is the choice of the turbulence model verification and boundary layer functions of the nozzle wall. Four different turbulence models are tested, and calculation results were 
compared with the experiments. It is stated that transient $\mathrm{k}-\omega$ models and RMS model give acceptable accuracy.

Results of the experiments and simulations are compared qualitatively for the shape and position of the recirculation zone and shock waves; and quantitatively, comparing the pressure distribution on the nozzle lower surface.

\section{ACKNOWLEDGMENT}

This paper is the part of the research on the project III47029 of MPN TR RS.

\section{REFERENCES}

[1] Živković, S.: Methods of thrust calculation in thrust vector control system process optimisation (in Serbian), in: Proceedings of the Yugoslav committee for explosive materials, 20-21.10.2004, Bar, pp. 89-97.

[2] Gal-Or B.: Fundamental Concepts of Vectored Propulsion, Journal of Propulsion, Vol. 6, No. 6, pp. 747-757, 1990.

[3] Jojić, B., Milinovic, M., Stefanović, Z. and Blagojević, D.: Pressure distribution in rocket nozzle with mechanical system for TVC, AIAA Paper 87-1824, June 1987.

[4] Zmijanović, V., Rašuo, B., Chpoun, A., Flow separation modes and side phenomena in an over expanded nozzle, FME Transactions, Vol. 40, No. 3, pp.111-118, 2012.

[5] Waithe, K. A. and Deere, K. A.: Experimental and computational investigation of multiple injection ports in a convergent-divergent nozzle for fluidic thrust vectoring, AIAA Paper 2003-3802, 2003.

[6] Kozic, M. and Ristic, S.: Capability of 2D RANS simulations for $2 \mathrm{D}$ thrust vectoring nozzle, Journal of Aerospace Engineering, Vol. 224, pp. 905-910, 2010.
[7] Tian, C. and Lu, Y.: Turbulence models of separated flow in shock wave thrust vector nozzle. Engineering Application of Computational Fluid Mechanics, Vol. 7, No. 2, pp. 182-192, 2013.

[8] Chang, P.: Control of flow separation, Hemisphere Publishing Corporation, Washington, 1976.

[9] ANSYS FLUENT, Theory Guide, Release 12.0., ANSYS Inc. Lebanon, 2011.

\section{ЕКСПЕРИМЕНТАЛНО И НУМЕРИЧКО ИСТРАЖИВАЊЕ СУПЕРСОНИЧНОГ \\ РАВАНСКОГ МЛАЗНИКА СА ВЕКТОРИСАНИМ ПОТИСКОМ МЕХАНИЧКИМ ПРЕПРЕКАМА}

\section{Саша Живковић, Момчило Милиновић, Норберт Адамец}

У испитивањима извршеним у аеротунелу употребљен је конвергентно-дивергентни млазник тестиран хладном струјом, са интерцептором као препреком на излазном пресеку млазника. Ова геометрија примењена је за управљање вектором потиска код вођених ракета. У току варијације најважнијих утицајних геометријских параметара у домену струјања, мерени су и приказани Шлирен фотографијама, поремећаји притиска на површини млазника. Користећи те експерименталне резултате спроведено је компјутерско моделирање струјања (CFD) и упоређена су четири модела турбуленције. Након поређења предност је дата прелазним k- $\omega$ турбулентним моделима, поређењем резултата по конкуретности и цени компјутерског прорачуна. Ови резултати могу се употребити као смернице за будућа тродимензионална CFD истраживања реалне геометрије управљања вектора потиска, али и такође, за боље разумевање струјних процеса код оваквих примена. 